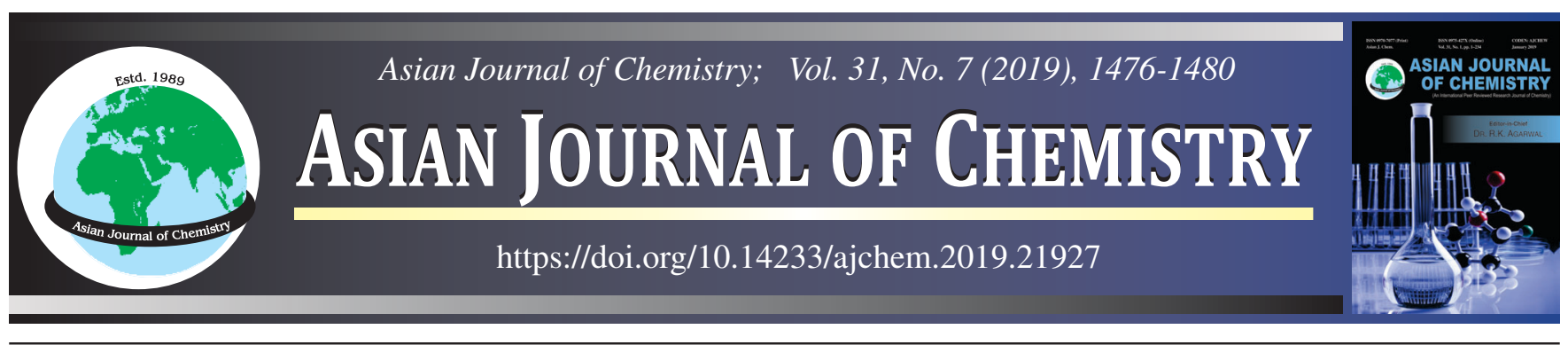

\title{
Solvation Behaviour of Some Copper(I) Complexes in Binary Mixtures of Dimethylsulfoxide with Dimethylacetamide and Dimethylformamide at $298 \mathrm{~K}$
}

\section{Bal Krishan Vermani ${ }^{1}$, Vivek Pathania ${ }^{1, *}$, Shashi Kiran Vermani ${ }^{2}$ and Shrutila Sharma ${ }^{1}$}

${ }^{1}$ Department of Chemistry, D.A.V. College, Chandigarh-160011, India

${ }^{2}$ Joint Director (Retd.) Higher Education, Haryana, Panchkula-134109, India

*Corresponding author: E-mail: viveksinghpathania@yahoo.com

Received: 8 January 2019;

Accepted: 25 February 2019;

Published online: 21 May 2019;

AJC-19400

\begin{abstract}
$\Gamma$
Molar conductance values of a large number of copper(I) perchlorate complexes behaving as strong 1:1 electrolytes, have been measured in binary mixtures of dimethylsulfoxide with dimethylacetamide and dimethylformamide at $298 \mathrm{~K}$. The measured conductance data have been analyzed to obtain the limiting molar conductance $\left(\Lambda_{0}\right)$ of these electrolytes. The limiting ion conductances $\left(\lambda_{ \pm}^{\circ}\right)$ for various ions in the binary mixtures of DMSO with DMA and DMF have been calculated by an indirect method using $\left[\mathrm{Bu}_{4} \mathrm{~N}\right] \mathrm{BPh}_{4}$ as a reference electrolyte. The actual ionic radii $\left(r_{i}\right)$ values for these copper(I) complex ions increase significantly with increase in DMA composition whereas the corresponding $r_{i}$ values for these ions do not show a significant increase with increase in DMF composition that indicates no preferential solvation of copper(I) complex ions for DMF over DMSO, thus showing that DMA solvates the copper(I) complex ions more strongly than DMF.
\end{abstract}

Keywords: Molar conductance, Limiting molar conductance, Limiting ion conductance, Solvated radii, Preferential solvation.

\section{INTRODUCTION}

Physico-chemical measurements of electrolytic solutions of various electrolytes in aqueous, non-aqueous and mixed solvents have attracted attention in recent years [1-4]. The solvation studies particularly the preferential solvation [5-10] behaviour of ions has been of significant importance in electrorefining and hydrometallurgy. Some other areas where these electrolytes have extensively been used include electro-chromic displays, smart window, etching and electro synthesis etc. [11]. Now-a-days, various strategies have been developed for assembling copper(I) complexes for use as dyes in dye sensitized solar cells [12]. Highly ionic copper(I) complexes like copper(I) perchlorate tetraacetonitrile $\left(\mathrm{CuClO}_{4} \cdot 4 \mathrm{AN}\right)$ and copper(I) perchlorate tetrabenzonitrile $\left(\mathrm{CuClO}_{4} \cdot 4 \mathrm{BN}\right)$ are unstable in water and a large number of organic solvents. These copper(I) complexes, however, have a marked stability in acetonitrile. Therefore, studies of such salts in pure and mixed solvents are still lacking. These copper(I) complexes, however, have a marked stability in acetonitrile [13] (AN), benzonitrile [14] (BN) and some other nitriles [15]. Some investigations [16] of the behaviour of these white coloured complexes have been made in pure acetonitrile and binary mixtures of acetonitrile with several other organic solvents. Some coloured (orange, violet and brown) copper(I) perchlorate complexes like $\mathrm{CuClO}_{4} \cdot \mathrm{n}$ (Ligand) ( $\mathrm{n}=2$ or 4 ) with some other ligands have also been now prepared but their behaviour in solution has not yet been investigated. These complexes are highly stable in the solid form and in solution and their ligands cannot be replaced easily by the solvent molecules. A complex of this type, bis(2,9-dimethyl1,10-phenanthroline) copper(I) perchlorate $\left(\mathrm{CuClO}_{4} \cdot 2 \mathrm{DMPhen}\right)$ is a deep orange complex having high solubility and marked stability in a number of organic solvents. This complex owing to its large copper(I) cation, $\left[\mathrm{Cu}(\mathrm{DMPhen})_{2}\right]^{+}$and high stability, has been used for carrying out some conductance and viscosity measurements in some pure and mixed solvents [17]. In continuation with our studies of the copper(I) complexes in solution, in the present paper, we report the molar conductances of some copper(I) perchlorate complexes in binary mixtures of DMSO with DMA and DMF so that their solution behaviour can be investigated thoroughly. DMSO, DMA and DMF were selected as solvents because copper(I) complexes had marked stability in these solvents.

This is an open access journal, and articles are distributed under the terms of the Creative Commons Attribution-NonCommercial-ShareAlike 4.0 (CC BY-NC-SA 4.0) International License which allows readers to freely read, download, copy, distribute, print, search, or link to the full texts of its articles and to use them for any other lawful non-commercial purpose as long as the original source is duly acknowledged. 


\section{EXPERIMENTAL}

Acetonitrile (AN) (99.8\%), benzonitrile (BN) (99.8\%), dimethylformamide (DMF) (99.5\%), dimethylacetamide (DMA) $(99.5 \%$ ) and dimethylsulfoxide (DMSO) (99.5\%), all from E. Merck, were purified by the methods as reported [18]. The dielectric constant ( $(\varepsilon)$, viscosity ( $\eta$ ) and density (d) of DMSO with DMA and DMF, which were used for the analysis of the present conductance data are reported in Tables 1 and 2 , respectively. These values are in good agreement with the values reported in the literature.

\section{TABLE-1}

DIELECTRIC CONSTANT $(\varepsilon)$, VISCOSITY $(\eta)$ AND DENSITY (d) OF BINARY MIXTURES OF DMSO + DMA AT $298 \mathrm{~K}$

\begin{tabular}{cccc}
\hline Mol \% DMA & $\varepsilon$ & $\eta(\mathrm{cP})$ & $\mathrm{d}\left(\mathrm{g} \mathrm{cm}^{-3}\right)$ \\
\hline 0 & 46.73 & 1.990 & 1.0960 \\
20 & 44.51 & 1.780 & 1.0580 \\
40 & 42.47 & 1.527 & 1.0217 \\
60 & 40.32 & 1.317 & 0.9918 \\
80 & 39.10 & 1.120 & 0.9617 \\
100 & 37.78 & 0.919 & 0.9365 \\
\hline Standard
\end{tabular}

TABLE-2

DIELECTRIC CONSTANT $(\varepsilon)$, VISCOSITY $(\eta)$ AND DENSITY (d) OF BINARY MIXTURES OF DMSO + DMF AT $298 \mathrm{~K}$

\begin{tabular}{cccc}
\hline Mol \% DMF & $\varepsilon$ & $\eta(\mathrm{cP})$ & $\mathrm{d}\left(\mathrm{g} \mathrm{cm}^{-3}\right)$ \\
\hline 0 & 46.73 & 1.990 & 1.0960 \\
20 & 44.02 & 1.718 & 1.0612 \\
40 & 41.58 & 1.490 & 1.0310 \\
60 & 40.19 & 1.221 & 0.9980 \\
80 & 38.10 & 0.989 & 0.9714 \\
100 & 36.70 & 0.796 & 0.9443 \\
\hline
\end{tabular}

Standard uncertainties are: $\mathrm{d}=2 \times 10^{-9} \mathrm{~g} \mathrm{~cm}^{-3}, \eta=0.02 \mathrm{cP}$

Tetrabutylammonium tetraphenylborate $\left(\mathrm{Bu}_{4} \mathrm{NBPh}_{4}\right)$ and tetrabutylammonium perchlorate $\left(\mathrm{Bu}_{4} \mathrm{NClO}_{4}\right)$, which were used as reference electrolytes in the present work were prepared by the methods already reported [19]. Sodium tetraphenylborate $\left(\mathrm{NaBPh}_{4}\right), 99.5 \%$ (CDH Chemicals) was used as received. Copper(I) perchlorate tetraacetonitrile $\left(\mathrm{CuClO}_{4} \cdot 4 \mathrm{AN}\right)$ was prepared by the reduction of copper(II) perchlorate hexahydrate $\mathrm{Cu}\left(\mathrm{ClO}_{4}\right)_{2} \cdot 6 \mathrm{H}_{2} \mathrm{O}$ by copper powder in warm acetonitrile (AN) $99.8 \%$ (E.Merck) following the method reported by Gill and Cheema [20]. The complex was recrystallized twice from pure dry acetonitrile under nitrogen atmosphere and dried at 60-70 ${ }^{\circ} \mathrm{C}$ by applying vacuum. For checking its purity, the salt was analyzed by its elemental analysis and by titrating it in acetonitrile against aqueous $\mathrm{KMnO}_{4}$ solution. Copper(I) perchlorate tetrabenzonitrile [21] $\left(\mathrm{CuClO}_{4} .4 \mathrm{BN}\right)$ was prepared from $\mathrm{Cu}\left(\mathrm{ClO}_{4}\right)_{2} \cdot 6 \mathrm{H}_{2} \mathrm{O}$ by reduction with copper powder in benzonitrile $(\mathrm{BN}) \cdot \mathrm{Cu}\left(\mathrm{ClO}_{4}\right)_{2} \cdot 6 \mathrm{H}_{2} \mathrm{O}$ was dissolved in anhydrous benzonitrile and the solution was heated at $70-80^{\circ} \mathrm{C}$. Copper powder (99.8\% NICE Chemicals) was added slowly with constant stirring until the solution became colourless. The hot solution was filtered and on cooling, white crystals separated out. These crystals were repeatedly washed with pure, dry cyclohexane to remove free benzonitrile and dried under vacuum at room temperature to obtain $\mathrm{CuClO}_{4} \cdot 4 \mathrm{BN}$. The analysis of
$\mathrm{CuClO}_{4} \cdot 4 \mathrm{BN}$ dissolved in acetonitrile by $\mathrm{KMnO}_{4}$ titration and by elemental analysis established its compositions. $\mathrm{CuClO}_{4} \cdot \mathrm{BN}$ was found to be more stable than $\mathrm{CuClO}_{4} \cdot 4 \mathrm{AN}$. All other copper(I) perchlorate complexes used in this study were prepared from $\mathrm{CuClO}_{4} \cdot \mathrm{AN}$ by mixing warm solutions of respective ligands with $\mathrm{CuClO}_{4} \cdot 4 \mathrm{AN}$ in acetonitrile in required proportions. The reaction mixture was heated to $60{ }^{\circ} \mathrm{C}$ for $20-30 \mathrm{~min}$ in each case and the solutions were allowed to cool at room temperature. The complexes were precipitated out by adding an inert solvent or by removing acetonitrile completely from the solution under vacuum. Toluene was added to precipitate out $\mathrm{CuClO}_{4}$.DMPhen from acetonitrile solution and cyclohexane was added to precipitate out bis(1,10-phenanthroline) copper(I) perchlorate $\left(\mathrm{CuClO}_{4} \cdot 2 \mathrm{Phen}\right)$. The complexes were then filtered and dried at $70{ }^{\circ} \mathrm{C}$ under vacuum for several hours. Bis $\left(2,2^{\prime}-\right.$ bipyridyl) copper(I) perchlorate $\left(\mathrm{CuClO}_{4} \cdot 2 \mathrm{Bipy}\right)$ and copper(I) perchlorate tetrathiourea $\left(\mathrm{CuClO}_{4} \cdot 4 \mathrm{TU}\right)$ being extremely soluble in acetonitrile, could not be easily separated out from the solution either by cooling or by adding an inert solvent. They were, however, separated out by removing acetonitrile completely under vacuum.

Molar conductances of $\left[\mathrm{Bu}_{4} \mathrm{~N}\right] \mathrm{BPh}_{4},\left[\mathrm{Bu}_{4} \mathrm{~N}\right] \mathrm{ClO}_{4}$ as well as of $\mathrm{Cu}(\mathrm{I})$ perchlorate complexes prepared above were measured with a calibrated digital conductivity meter (Model ZM2376 LCR METER) from NF Corporation, Japan. Measurements were carried out in the concentration range $(1-60) \times 10^{-4} \mathrm{~mol}$ $\mathrm{dm}^{-3}$ in pure DMSO, DMA and DMF and in the binary mixtures of DMSO + DMA and DMSO + DMF containing 0, 20, 40, 60,80 and $100 \mathrm{~mol} \%$ DMA and DMF, respectively at $298 \mathrm{~K}$. The details of the experimental procedure of conductance measurements were the same as given previously $[19,22]$. The overall accuracy of the conductance measurements was found to be \pm $0.2 \%$. The cell constant of conductivity cell (Shedlovsky model) was determined by using several concentrations of $\mathrm{KCl}$ solutions in conductivity water. All solutions were prepared by mass (weighed by ACZET-602 CY). Working solutions for measurement of conductance were obtained by adding stock solutions of appropriate concentration to a known quantity of solvent or the binary mixture of solvents under study. The measurements were made in a thermostated water bath maintained at temperature $298 \mathrm{~K}$.

The viscosities of various binary mixtures were measured using model SV-10 Vibroviscometer from A\&D Company, Ltd. Japan The accuracy of viscosity measurements was found to be $\pm 1 \%$. The instrument was calibrated with the standard viscosity samples supplied with the instrument. The dielectric constants of the above binary mixtures were determined using Dielectric Constant Meter (Model DCM1 [Freq. $1 \mathrm{MHz}]$ ) with accuracy $\pm 1 \%$.

\section{RESULTS AND DISCUSSION}

Molar conductances of $\left[\mathrm{Bu}_{4} \mathrm{~N}\right] \mathrm{BPh}_{4},\left[\mathrm{Bu}_{4} \mathrm{~N}\right] \mathrm{ClO}_{4}$ and copper(I) perchlorate complexes have been measured in the concentration range $(1-60) \times 10^{-4} \mathrm{~mol} / \mathrm{dm}^{3}$ in binary mixtures of DMSO with DMA and DMF at 298K. The limiting molar conductances $\left(\Lambda_{\mathrm{o}}\right)$ reported in Tables 3 and 4 have been iteratively calculated by a least square treatment carried out computationally. As the precision of our conductance data is not better 
TABLE-3

LIMITING MOLAR CONDUCTANCE $\left(\Lambda_{\mathrm{o}}\right)\left(\mathrm{S} \mathrm{cm}^{2} \mathrm{~mol}^{-1}\right)$ FOR SOME SALTS IN DMSO + DMA MIXTURES AT $298 \mathrm{~K}$

\begin{tabular}{lcccccc}
\hline \multirow{2}{*}{\multicolumn{1}{c}{ Salt }} & \multicolumn{5}{c}{ Mol \% DMA } \\
\cline { 2 - 6 } & 0 & 20 & 40 & 60 & 80 & 100 \\
\hline $\mathrm{Bu}_{4} \mathrm{NBPh}_{4}$ & 22.24 & 24.48 & 27.95 & 31.81 & 36.72 & 43.80 \\
$\mathrm{Bu}_{4} \mathrm{NClO}_{4}$ & 36.12 & 38.89 & 43.68 & 47.47 & 52.60 & 62.50 \\
{$\left[\mathrm{Cu}(\mathrm{AN})_{4}\right] \mathrm{ClO}_{4}$} & 39.84 & 42.06 & 45.49 & 48.94 & 53.12 & 62.70 \\
{$\left[\mathrm{Cu}(\mathrm{BN})_{4}\right] \mathrm{ClO}_{4}$} & 39.87 & 41.50 & 45.00 & 47.92 & 52.19 & 61.50 \\
{$\left[\mathrm{Cu}(\mathrm{Phen})_{2}\right] \mathrm{ClO}_{4}$} & 35.93 & 37.89 & 41.61 & 44.82 & 48.90 & 68.40 \\
{$\left[\mathrm{Cu}(\mathrm{DMPhen})_{2}\right] \mathrm{ClO}_{4}$} & 35.33 & 37.31 & 41.04 & 44.21 & 48.27 & 57.05 \\
{$\left[\mathrm{Cu}(\mathrm{Bipy})_{2}\right] \mathrm{ClO}_{4}$} & 37.77 & 39.27 & 42.92 & 46.22 & 50.35 & 70.20 \\
{$\left[\mathrm{Cu}(\mathrm{TU})_{4}\right] \mathrm{ClO}_{4}$} & 39.77 & 42.04 & 46.57 & 50.06 & 55.52 & 64.50 \\
\hline
\end{tabular}

TABLE-4

LIMITING MOLAR CONDUCTANCE $\left(\Lambda_{\mathrm{o}}\right)\left(\mathrm{S} \mathrm{cm}^{2} \mathrm{~mol}^{-1}\right)$ FOR SOME SALTS IN DMSO + DMF MIXTURES AT $298 \mathrm{~K}$

\begin{tabular}{|c|c|c|c|c|c|c|}
\hline \multirow{2}{*}{ Salt } & \multicolumn{6}{|c|}{ Mol \% DMF } \\
\hline & 0 & 20 & 40 & 60 & 80 & 100 \\
\hline $\mathrm{Bu}_{4} \mathrm{NBPh}_{4}$ & 22.24 & 25.37 & 28.59 & 34.29 & 41.49 & 50.71 \\
\hline $\mathrm{Bu}_{4} \mathrm{NClO}_{4}$ & 36.12 & 40.24 & 46.28 & 52.89 & 63.08 & 76.32 \\
\hline$\left[\mathrm{Cu}(\mathrm{AN})_{4}\right] \mathrm{ClO}_{4}$ & 39.84 & 44.06 & 50.46 & 57.06 & 67.14 & 81.19 \\
\hline$\left[\mathrm{Cu}(\mathrm{BN})_{4}\right] \mathrm{ClO}_{4}$ & 39.87 & 44.08 & 49.81 & 56.35 & 67.16 & 81.20 \\
\hline$\left[\mathrm{Cu}(\mathrm{Phen})_{2}\right] \mathrm{ClO}_{4}$ & 35.93 & 39.85 & 45.48 & 51.97 & 61.48 & 74.41 \\
\hline$\left[\mathrm{Cu}(\mathrm{DMPhen})_{2}\right] \mathrm{ClO}_{4}$ & 35.33 & 38.87 & 44.81 & 51.14 & 60.54 & 73.28 \\
\hline$\left[\mathrm{Cu}(\text { Bipy })_{2}\right] \mathrm{ClO}_{4}$ & 37.77 & 41.43 & 47.60 & 53.92 & 63.87 & 77.03 \\
\hline$\left[\mathrm{Cu}(\mathrm{TU})_{4}\right] \mathrm{ClO}_{4}$ & 39.77 & 44.04 & 50.44 & 57.04 & 67.98 & 81.18 \\
\hline
\end{tabular}

than $\pm 0.2 \%$, the use of any other conductance equation, which demands a precision in a conductance data much better than \pm $0.1 \%$ was not thought worthwhile to analyze the present conductance data.

Limiting ion conductances $\left(\boldsymbol{\lambda}_{ \pm}^{\circ}\right)$ : The use of an indirect method $[16,23]$ based on eqns. 1 and 2 has been used to calculate $\lambda^{\circ}$ values of all ions in the various binary mixtures of DMSO with DMA and DMF.

$$
\begin{gathered}
\frac{\lambda_{ \pm}^{o}\left[\mathrm{Bu}_{4} \mathrm{~N}^{+}\right]}{\lambda_{ \pm}^{o}\left[\mathrm{Ph}_{4} \mathrm{~B}^{-}\right]}=\frac{5.35-\left(0.0103 \varepsilon+\mathrm{r}_{\mathrm{y}}\right)}{5.00-\left(0.0103 \varepsilon+\mathrm{r}_{\mathrm{y}}\right)} \\
\lambda_{ \pm}^{\mathrm{o}}\left[\mathrm{Bu}_{4} \mathrm{~N}^{+}\right]+\lambda_{ \pm}^{o}\left[\mathrm{Ph}_{4} \mathrm{~B}^{-}\right]=\Lambda_{\mathrm{o}}\left[\mathrm{Bu}_{4} \mathrm{NBPh}_{4}\right]
\end{gathered}
$$

The $\lambda_{ \pm}{ }^{\circ}$ values for various ions have been reported in Tables 5 and 6.

Ionic radii $\left(\mathbf{r}_{\mathrm{i}}\right)$ of complex ions in solution: Using Gill's modification of Robinson-Stokes's law [24]:

$$
r_{i}=\frac{|Z| F^{2}}{6 \pi \eta N \lambda_{ \pm}^{o}}+0.0103 \varepsilon+r_{y}
$$

where $r_{i}$ is the actual radius of an ion in solution, $\varepsilon$ is the dielectric constant of the medium and $\mathrm{r}_{\mathrm{y}}$ is an adjustable parameter taken as $0.113 \mathrm{~nm}$ for DMSO and $0.085 \mathrm{~nm}$ for DMA and DMF. All other parameters have their usual significance [22]. Using $\lambda_{ \pm}^{\circ}$ values from Tables 5 and 6 the $r_{i}$ values for various ions have been calculated in binary mixtures of DMSO with DMA and DMF and are also reported in Tables 5 and 6. A perusal of Table- 5 shows that the $\mathrm{r}_{\mathrm{i}}$ values for $\mathrm{Bu}_{4} \mathrm{~N}^{+}$and $\mathrm{Ph}_{4} \mathrm{~B}^{-}$, are almost constant and nearly equal to their crystallographic radii $(0.50 \mathrm{~nm}$ and $0.535 \mathrm{~nm}$, respectively) [22]. These two ions because of their large size do not get solvated in many dipolar aprotic solvents [22]. The copper(I) complex ions show some interesting results. The $\mathrm{r}_{\mathrm{i}}$ values for all copper(I) complex ions are quite large. Several of these copper(I) complex ions especially $\left[\mathrm{Cu}(\mathrm{Phen})_{2}\right]^{+}$and $\left[\mathrm{Cu}(\mathrm{DMPhen})_{2}\right]^{+}$have relatively larger ionic radii as compared to $\mathrm{Bu}_{4} \mathrm{~N}^{+}$throughout the whole

\begin{tabular}{|c|c|c|c|c|c|c|c|c|c|c|c|c|}
\hline \multicolumn{13}{|c|}{$\begin{array}{l}\text { TABLE- } 5 \\
\text { LIMITING IONIC CONDUCTANCES }\left(\lambda_{ \pm}^{\circ}\right)\left(\mathrm{S} \mathrm{cm}^{2} \mathrm{~mol}^{-1}\right) \text { AND SOLVATED } \\
\text { RADII }\left(\mathrm{r}_{\mathrm{i}}\right)(\mathrm{nm}) \text { FOR SOME IONS IN DMSO + DMA MIXTURES AT } 298 \mathrm{~K}\end{array}$} \\
\hline \multirow{3}{*}{ Ion } & \multicolumn{12}{|c|}{ Mol \% DMA } \\
\hline & \multicolumn{2}{|c|}{0} & \multicolumn{2}{|c|}{20} & \multicolumn{2}{|c|}{40} & \multicolumn{2}{|c|}{60} & \multicolumn{2}{|c|}{80} & \multicolumn{2}{|c|}{100} \\
\hline & $\lambda^{\circ}$ & $r_{i}$ & $\lambda^{\circ}$ & $r_{i}$ & $\lambda^{\circ}$ & $r_{i}$ & $\lambda^{\circ}$ & $r_{i}$ & $\lambda^{\circ}$ & $r_{i}$ & $\lambda^{\circ}$ & $r_{i}$ \\
\hline $\mathrm{Bu}_{4} \mathrm{~N}^{+}$ & 11.67 & 0.51 & 12.89 & 0.51 & 14.70 & 0.51 & 16.72 & 0.51 & 19.28 & 0.51 & 22.90 & 0.51 \\
\hline $\mathrm{Ph}_{4} \mathrm{~B}^{-}$ & 10.57 & 0.55 & 11.59 & 0.55 & 13.25 & 0.55 & 15.09 & 0.55 & 17.44 & 0.55 & 20.90 & 0.55 \\
\hline $\mathrm{ClO}_{4}^{-}$ & 24.45 & 0.33 & 26.00 & 0.33 & 28.98 & 0.33 & 30.75 & 0.34 & 33.32 & 0.35 & 39.60 & 0.35 \\
\hline$\left[\mathrm{Cu}(\mathrm{AN})_{4}\right]^{+}$ & 15.39 & 0.43 & 16.06 & 0.44 & 16.51 & 0.47 & 18.19 & 0.48 & 19.80 & 0.50 & 23.10 & 0.51 \\
\hline$\left[\mathrm{Cu}(\mathrm{BN})_{4}\right]^{+}$ & 15.42 & 0.43 & 15.50 & 0.45 & 16.02 & 0.48 & 17.17 & 0.50 & 18.87 & 0.52 & 21.9 & 0.53 \\
\hline$\left[\mathrm{Cu}(\mathrm{Phen})_{2}\right]^{+}$ & 11.48 & 0.52 & 11.89 & 0.54 & 12.63 & 0.57 & 14.07 & 0.58 & 15.58 & 0.60 & 28.80 & 0.62 \\
\hline$\left[\mathrm{Cu}(\text { DMPhen })_{2}\right]^{+}$ & 10.88 & 0.54 & 11.31 & 0.56 & 12.06 & 0.59 & 13.46 & 0.60 & 14.95 & 0.62 & 17.45 & 0.64 \\
\hline$\left[\mathrm{Cu}(\text { Bipy })_{2}\right]^{+}$ & 12.92 & 0.48 & 13.27 & 0.50 & 13.94 & 0.53 & 15.47 & 0.54 & 17.03 & 0.56 & 30.60 & 0.58 \\
\hline$\left[\mathrm{Cu}(\mathrm{TU})_{4}\right]^{+}$ & 15.32 & 0.43 & 16.04 & 0.44 & 17.59 & 0.45 & 19.31 & 0.46 & 22.20 & 0.46 & 24.90 & 0.48 \\
\hline
\end{tabular}
composition of DMSO + DMA mixtures. Other copper(I) complex ions $\left[\mathrm{Cu}(\mathrm{AN})_{4}\right]^{+},\left[\mathrm{Cu}(\mathrm{BN})_{4}\right]^{+}$and $\left[\mathrm{Cu}(\mathrm{Bipy})_{2}\right]^{+}$have relatively smaller ionic radii as compared to $\mathrm{Bu}_{4} \mathrm{~N}^{+}$in pure DMSO but, 
TABLE-6

LIMITING IONIC CONDUCTANCES $\left(\lambda_{ \pm}^{\circ}\right)\left(\mathrm{S} \mathrm{cm}^{2} \mathrm{~mol}^{-1}\right)$ AND SOLVATED

RADII $\left(r_{i}\right)(n m)$ FOR SOME IONS IN DMSO + DMF MIXTURES AT $298 \mathrm{~K}$

\begin{tabular}{|c|c|c|c|c|c|c|c|c|c|c|c|c|}
\hline \multirow{3}{*}{ Ion } & \multicolumn{12}{|c|}{ Mol \% DMF } \\
\hline & \multicolumn{2}{|c|}{0} & \multicolumn{2}{|c|}{20} & \multicolumn{2}{|c|}{40} & \multicolumn{2}{|c|}{60} & \multicolumn{2}{|c|}{80} & \multicolumn{2}{|c|}{100} \\
\hline & $\lambda^{\circ}$ & $\mathrm{r}_{\mathrm{i}}$ & $\lambda^{\circ}$ & $\mathrm{r}_{\mathrm{i}}$ & $\lambda^{\circ}$ & $\mathrm{r}_{\mathrm{i}}$ & $\lambda^{\circ}$ & $\mathrm{r}_{\mathrm{i}}$ & $\lambda^{\circ}$ & $\mathrm{r}_{\mathrm{i}}$ & $\lambda^{\circ}$ & $\mathrm{r}_{\mathrm{i}}$ \\
\hline $\mathrm{Bu}_{4} \mathrm{~N}^{+}$ & 11.67 & 0.51 & 13.37 & 0.51 & 15.05 & 0.51 & 18.02 & 0.51 & 21.78 & 0.51 & 26.60 & 0.51 \\
\hline $\mathrm{Ph}_{4} \mathrm{~B}^{-}$ & 10.57 & 0.55 & 12.00 & 0.55 & 13.54 & 0.55 & 16.27 & 0.55 & 19.71 & 0.55 & 24.11 & 0.55 \\
\hline $\mathrm{ClO}_{4}^{-}$ & 24.45 & 0.33 & 26.87 & 0.33 & 31.23 & 0.32 & 34.87 & 0.33 & 41.30 & 0.33 & 49.72 & 0.33 \\
\hline$\left[\mathrm{Cu}(\mathrm{AN})_{4}\right]^{+}$ & 15.39 & 0.43 & 17.19 & 0.43 & 19.23 & 0.43 & 22.19 & 0.44 & 25.84 & 0.45 & 31.47 & 0.45 \\
\hline$\left[\mathrm{Cu}(\mathrm{BN})_{4}\right]^{+}$ & 15.42 & 0.43 & 17.21 & 0.43 & 18.58 & 0.44 & 21.48 & 0.45 & 25.86 & 0.45 & 31.48 & 0.45 \\
\hline$\left[\mathrm{Cu}(\mathrm{Phen})_{2}\right]^{+}$ & 11.48 & 0.52 & 12.98 & 0.52 & 14.25 & 0.53 & 17.10 & 0.53 & 20.18 & 0.54 & 24.69 & 0.54 \\
\hline$\left[\mathrm{Cu}(\mathrm{DMPhen})_{2}\right]^{+}$ & 10.88 & 0.54 & 12.00 & 0.55 & 13.58 & 0.55 & 16.27 & 0.55 & 19.24 & 0.56 & 23.56 & 0.56 \\
\hline$\left[\mathrm{Cu}(\text { Bipy })_{2}\right]^{+}$ & 12.92 & 0.48 & 14.56 & 0.48 & 16.37 & 0.48 & 19.05 & 0.49 & 22.57 & 0.50 & 27.31 & 0.50 \\
\hline$\left[\mathrm{Cu}(\mathrm{TU})_{4}\right]^{+}$ & 15.32 & 0.43 & 17.17 & 0.43 & 19.21 & 0.43 & 22.17 & 0.44 & 26.68 & 0.44 & 31.46 & 0.45 \\
\hline
\end{tabular}

these ionic radii tend to become greater than that for $\mathrm{Bu}_{4} \mathrm{~N}^{+}$as the DMA composition increases, i.e., in the DMA rich region. $\left[\mathrm{Cu}(\mathrm{TU})_{4}\right]^{+}$however, has relatively smaller ionic radii than $\mathrm{Bu}_{4} \mathrm{~N}^{+}$throughout the whole composition range of DMSO + DMA mixtures. Also the $r_{i}$ values for these copper(I) complex ions increase significantly with increase in DMA composition. This is expected because DMA molecule has larger size than that of DMSO molecule. These results show that these copper(I) complex ions get solvated considerably as the composition of DMA in the binary mixture increases. $\mathrm{ClO}_{4}^{-}$has $\mathrm{r}_{\mathrm{i}}$ values, which show a slight increase with increase in DMA composition but are larger than its crystallographic radius $(0.260 \mathrm{~nm})$. This ion thus shows some solvation effect throughout the DMSO + DMA composition range.A perusal of Table- 6 shows that the $r_{i}$ values for $\mathrm{Bu}_{4} \mathrm{~N}^{+}$and $\mathrm{Ph}_{4} \mathrm{~B}^{-}$, are almost constant and nearly equal to their crystallographic radii $(0.50 \mathrm{~nm}$ and $0.535 \mathrm{~nm}$, respectively) [22]. These two ions because of their large size do not get solvated in many dipolar aprotic solvents [24]. The $r_{i}$ values for all copper(I) complex ions are relatively smaller than those for DMSO + DMF mixtures. Several of these copper(I) complex ions especially $\left[\mathrm{Cu}(\mathrm{Phen})_{2}\right]^{+}$and $\left[\mathrm{Cu}(\text { DMPhen })_{2}\right]^{+}$ have relatively larger ionic radii as compared to $\mathrm{Bu}_{4} \mathrm{~N}^{+}$throughout the whole composition range of DMSO + DMF mixtures. Other copper(I) complex ions $\left[\mathrm{Cu}(\mathrm{AN})_{4}\right]^{+},\left[\mathrm{Cu}(\mathrm{BN})_{4}\right]^{+}$, $\left[\mathrm{Cu}(\mathrm{Bipy})_{2}\right]^{+}$and $\left[\mathrm{Cu}(\mathrm{TU})_{4}\right]^{+}$have relatively smaller ionic radii as compared to $\mathrm{Bu}_{4} \mathrm{~N}^{+}$throughout the DMSO + DMF composition range. Also the $r_{i}$ values for these copper(I) complex ions increase slightly with increase in DMF composition. This is expected because DMF molecule has a slightly large size than that of DMSO molecule. These results show that these copper(I) complex ions do not get solvated to a great extent as the composition of DMF in the binary mixtures increases. Looking at the results of $\mathrm{r}_{\mathrm{i}}$ values from Tables 5 and 6 , we conclude that DMA solvates the copper(I) complex ions more strongly than DMF

\section{Conclusion}

Copper(I) perchlorate complexes with ligands acetonitrile, benzonitrile, Phen, DMPhen, Bipy and TU get solvated in DMSO + DMA solvent mixtures and the extent of solvation increases in the DMA-rich region. The solvated radii for $\mathrm{Bu}_{4} \mathrm{~N}^{+}$ and $\mathrm{Ph}_{4} \mathrm{~B}^{-}$remain constant in both DMSO + DMA and DMSO + DMF solvent systems showing that these ions do not get solvated in dipolar aprotic solvents. The ionic radii $\left(r_{i}\right)$ for the complex ions $\left[\mathrm{Cu}(\text { Phen })_{2}\right]^{+},\left[\mathrm{Cu}(\text { DMPhen })_{2}\right]^{+}$and $\left[\mathrm{Cu}(\text { Bipy })_{2}\right]^{+}$ are much larger and for complex ions $\left[\mathrm{Cu}(\mathrm{AN})_{4}\right]^{+},\left[\mathrm{Cu}(\mathrm{BN})_{4}\right]^{+}$ and $\left[\mathrm{Cu}(\mathrm{TU})_{4}\right]^{+}$are smaller than that for the ion $\mathrm{Bu}_{4} \mathrm{~N}^{+}$throughout the DMSO + DMA composition range. The solvated radii of $\mathrm{ClO}_{4}^{-}$ion increase with increase in composition of DMA showing preferential solvation by DMA in DMSO + DMA mixtures. However, the solvated radii for $\mathrm{Cu}^{+}$complex ions and $\mathrm{ClO}_{4}^{-}$remain almost constant in DMSO + DMF solvent systems showing no preferential solvation by DMF. We thus conclude that the extent of solvation of Copper complex ions and $\mathrm{ClO}_{4}^{-}$is much more pronounced in the DMA-rich region as compared to the DMF-rich region.

\section{ACKNOWLEDGEMENTS}

The authors thank D.A.V. College, Chandigarh, India for financial assistance.

\section{CONFLICT OF INTEREST}

The authors declare that there is no conflict of interests regarding the publication of this article.

\section{REFERENCES}

1. D.S. Gill, A. Kumari, R. Gupta, S.P. Jauhar and J.K. Puri, Z. Phys. Chem., 219, 1099 (2005);

https://doi.org/10.1524/zpch.2005.219.8.1099.

2. D.S. Gill, V. Pathania, B.K. Vermani and R.P. Sharma, Z. Phys. Chem., 217, 739 (2003); https://doi.org/10.1524/zpch.217.6.739.20446.

3. D.S. Gill, H. Anand, A. Kumari and J.K. Puri, Z. Naturforsch., 59a, 615 (2004);

https://doi.org/10.1515/zna-2004-0912.

4. D.S. Gill, V. Pathania, A. Kumari, H. Anand and S.P. Jauhar, Z. Phys. Chem., 218, 857 (2004);

https://doi.org/10.1524/zpch.218.7.857.35729.

5. H.F. Tooski, M. Jabbari and A. Farajtabar, J. Solution Chem., 45, 1701 (2016); https://doi.org/10.1007/s10953-016-0526-2.

6. D.R. Delgado and F. Martinez, J. Mol. Liq., 193, 152 (2014); https://doi.org/10.1016/j.molliq.2013.12.021.

7. G.Q. Chen, J. Chen, C. Cheng, Y. Cong, C.B. Du and H.K. Zhao, J. Chem. Thermodyn., 111, 228 (2017); https://doi.org/10.1016/j.jct.2017.03.038.

8. X.B. Li, C. Cheng, Y. Cong, C.B. Du and H.K. Zhao, J. Chem. Thermodyn., 110, 218 (2017);

https://doi.org/10.1016/j.jct.2017.03.005

9. Z.J. Cardenas, D.M. Jimenez, D.R. Delgado, O.A. Almanza, A. Jouyban, F. Martinez and W.E. Acree Jr., J. Chem. Thermodyn., 108, 26 (2017); https://doi.org/10.1016/j.jct.2017.01.005 
10. M. Zheng, A. Farajtabar and H. Zhao, J. Mol. Liq., 264, 285 (2018); https://doi.org/10.1016/j.molliq.2018.05.057.

11. X. Liu, Z. Sun, S. Cui and P. Du, Electrochim. Acta, 187, 381 (2016); https://doi.org/10.1016/j.electacta.2015.11.059.

12. C.E. Housecroft and E.C. Constable, Chem. Soc. Rev., 44, 8386 (2015); https://doi.org/10.1039/C5CS00215J.

13. D.S. Gill and D. Rana, Z. Naturforsch., 64a, 269 (2009); https://doi.org/10.1515/zna-2009-3-416.

14. D.S. Gill and P. Singh, Indian J. Chem., 38A, 478 (1999).

15. D.S. Gill, J. Singh, R. Singh, T. Zamir and T.I. Quickenden, Indian J. Chem., 38A, 913 (1999).

16. D.S. Gill, D.S. Rana and S.P. Jauhar, Z. Phys. Chem., 225, 69 (2011); https://doi.org/10.1524/zpch.2011.5527.

17. D.S. Gill and V. Pathania, Adv. Inorg. Chem., 68, 2847 (2016); https://doi.org/10.1016/bs.adioch.2015.11.001.

18. J.A. Riddick, W.B. Bunger and T.K. Sakano, Organic Solvents, Physical Properties and Methods of Purification, Wiley Interscience: New York, edn 4 (1986).
19. D.S. Gill, A.N. Sharma and H. Schneider, J. Chem. Soc., Faraday Trans., 78, 465 (1982); https://doi.org/10.1039/f19827800465.

20. D.S. Gill and J.S. Cheema, Electrochim. Acta, 27, 1267 (1982); https://doi.org/10.1016/0013-4686(82)80147-3.

21. D.S. Gill, L. Rodehüser, P. Rubini and J.-J. Delpuech, J. Chem. Soc., Faraday Trans., 91, 2307 (1995);

https://doi.org/10.1039/FT9959102307.

22. D.S. Gill and M.B. Sekhri, J. Chem. Soc., Faraday Trans. I, 78, 119 (1982); https://doi.org/10.1039/f19827800119.

23. B. Das, N. Saha and D.K. Hazra, J. Chem. Eng. Data, 45, 353 (2000); https://doi.org/10.1021/je990239z.

24. D.S. Gill, Electrochim. Acta, 24, 701 (1979); https://doi.org/10.1016/0013-4686(79)87054-1. 